\title{
A folyóirat olvasottságáról
}

\author{
About the journal popularity
}

doi: $10.24365 /$ ef.v58i3.193

A szerkesztőség örömmel jelzi vissza olvasóinak, hogy a folyóirat olvasottsága az elektronikus változatra való áttéréstől, 2016 elejétől folyamatosan emelkedik: idén a havi látogatószám már átlagosan 4000, az átlagos napi látogatószám pedig 130 felett jár. [1. ábra]

1. ábra: A folyóirat honlapját havonta illetve naponta átlagosan meglátogatók száma

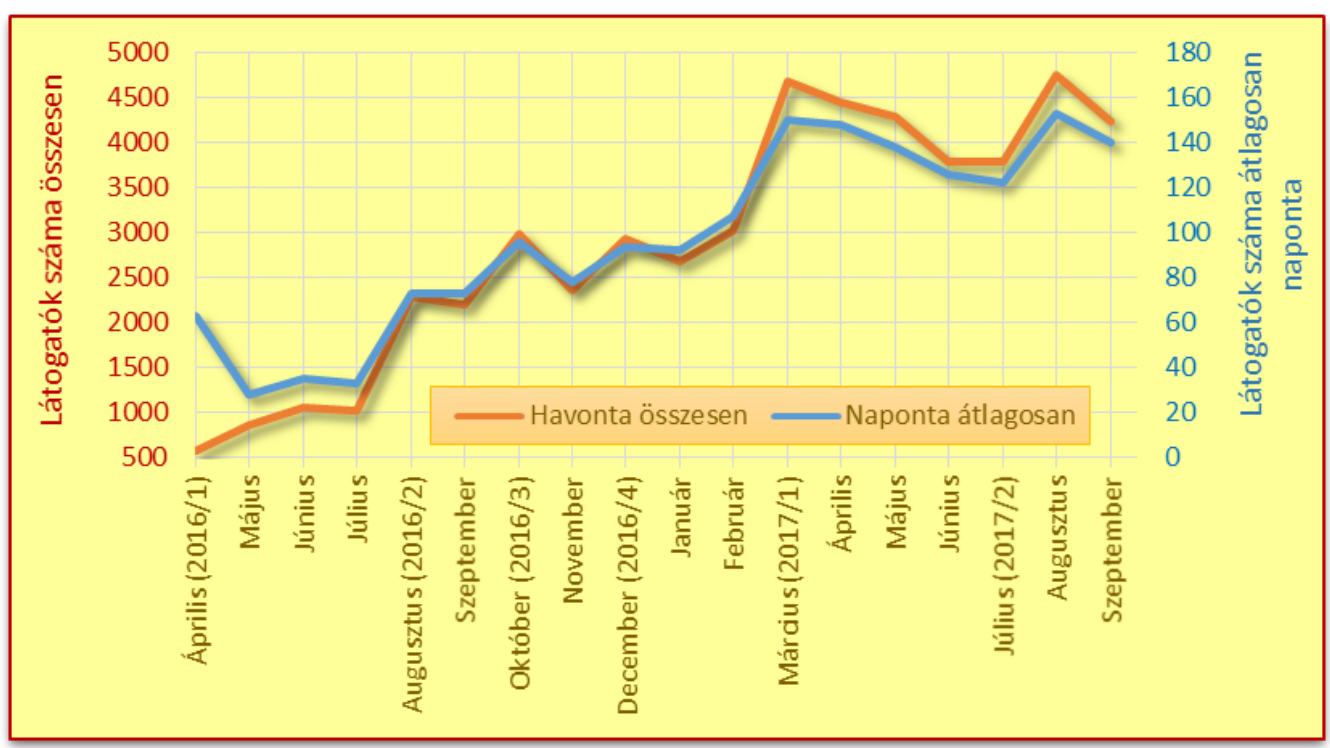

A lapszámok olvasottsági statisztikái mellett érdekes lehet, hogy mely témák érdeklik leginkább az olvasókat. A folyóirat elektronikus megjelentetése lehetővé teszi, hogy minden egyes közlemény esetében nyomon követhető, hányan nézték meg az írás összefoglalóját, illetve hányan olvasták el a teljes cikket. A 2016. év első számától kezdődően eddig megjelent múvek közül kiválogattuk azokat, amelyek összefoglalóit, illetve amelyek teljes szövegét a legtöbbször olvasták el 2017. szeptember 30-ig. [1. táblázat és 2. táblázat]

Figyelembe véve azt az időt is, ami a közlés után eltelt, azaz a cikkekhez való hozzáférés hosszát is, egy „érdekességi” mutató számítható (megtekintések száma / megjelenés óta eltelt napok száma). Az e mutató alapján összeállított 10-es listát a 3. táblázat mutatja be.
Érdemes felhívni a figyelmet arra, hogy a 10 legtöbbször olvasott összefoglaló között az iskolai egészségfejlesztés 4 közleménnyel is képviselteti magát. [1. táblázat] Két írás foglalkozott az egészségmúveltséggel, vagy másképpen az egészségértéssel.

A teljes közlemény olvasottságát tekintve kiemelkedik az első három helyezett, közülük is a csecsemőkori allergia-megelőzést tárgyaló írás, ami a hasonló témájú cikkek iránti magas olvasói igényre utal, és ez a potenciális szerzők számára felhívásként értelmezhető. [2. táblázat]

Meglepőnek tűnhet továbbá a két szerkesztőségi közlés előkelő helyezése is. Feltételezhető, hogy a népegészségügyi háttérintézmények átszervezésével kapcsolatosan vált érdekessé a téma. 
1. táblázat: A közlemények összefoglalóira vonatkozó olvasottsági rangsor

\begin{tabular}{|c|c|c|c|}
\hline $\begin{array}{l}\text { Megtekintések } \\
\text { száma }\end{array}$ & Közlemény címe & Szerző(k) & Lapszám \\
\hline 373 & $\begin{array}{l}\text { Egészséges életmóddal kapcsolatos kutatások a hazai } \\
\text { iskolákban }\end{array}$ & $\begin{array}{c}\text { Járomi É, Szilágyi K, } \\
\text { Vitrai J }\end{array}$ & 2016. 1. szám \\
\hline 237 & $\begin{array}{l}\text { A magyarországi egészségértés nemzetközi összehasonlí- } \\
\text { tásban }\end{array}$ & Koltai J, Kun E & 2016. 3. szám \\
\hline 236 & Új hazai egészségmonitorozási koncepció & Varsányi P et al. & 2016. 1. szám \\
\hline 225 & $\begin{array}{l}\text { Egészségkommunikációs Felmérés Eredményei I. } \\
\text { - Felnőtt felmérés }\end{array}$ & Balku E, Vitrai J & 2016. 2. szám \\
\hline 207 & Az egészségműveltség definíciói & Csizmadia P & 2016. 3. szám \\
\hline 189 & $\begin{array}{l}\text { Egészségkommunikációs Felmérés Eredményei II. } \\
\text { - Iskolai felmérés }\end{array}$ & $\begin{array}{l}\text { Zsiros E, Balku E, } \\
\text { Vitrai J }\end{array}$ & 2016. 3. szám \\
\hline 175 & $\begin{array}{l}\text { „Egészség-konyha” - Munkahelyi egészségfejlesztési } \\
\text { programelem a Nemzeti Egészségfejlesztési Intézetben }\end{array}$ & Fekete K & 2016. 4. szám \\
\hline 172 & $\begin{array}{l}\text { Az iskolai egészségfejlesztés hazai és nemzetközi szemléle- } \\
\text { tének bemutatatása }\end{array}$ & Járomi É, Vitrai J & 2017. 1. szám \\
\hline 165 & $\begin{array}{l}\text { Hálózatkutatás a népegészségügy területén - áttekintő } \\
\text { közlemény }\end{array}$ & Varsányi P, Vokó Z & 2016. 4. szám \\
\hline 153 & $\begin{array}{l}\text { A rendszeres reggelizés mint szokáskialakítás és értékköz- } \\
\text { vetítés a középiskolás korosztályban }\end{array}$ & Lelovics Zs & 2017. 1. szám \\
\hline
\end{tabular}

\section{2. táblázat: A teljes közleményre vonatkozó olvasottsági rangsor}

\begin{tabular}{|c|c|c|c|}
\hline $\begin{array}{l}\text { Megtekintések } \\
\text { száma }\end{array}$ & Közlemény címe & Szerző(k) & Lapszám \\
\hline 890 & $\begin{array}{l}\text { A csecsemőkori allergia-megelőzés korszerű irányelvei és } \\
\text { lehetőségei }\end{array}$ & Réthy $\mathrm{A}$ & 2017. 1. szám \\
\hline 304 & Egészségfejlesztési Irodák hálózata & Bezzegh P & 2016. 1. szám \\
\hline 278 & $\begin{array}{l}\text { Egészséges életmóddal kapcsolatos kutatások a hazai is- } \\
\text { kolákban }\end{array}$ & $\begin{array}{l}\text { Járomi É, Szilágyi K, } \\
\text { Vitrai J }\end{array}$ & 2016. 1. szám \\
\hline 191 & $\begin{array}{l}\text { Az iskolai egészségfejlesztés hazai és nemzetközi szemlé- } \\
\text { letének bemutatatása }\end{array}$ & Járomi É, Vitrai J & 2017. 1. szám \\
\hline 165 & $\begin{array}{l}\text { OKOSTÁNYÉR }{ }^{\circledR} \text { - új táplálkozási ajánlás a hazai felnőtt la- } \\
\text { kOsság számára }\end{array}$ & Szúcs Zs & 2016. 4. szám \\
\hline 162 & $\begin{array}{l}\text { Beszélgetés a folyóiratról Dr. Surján Orsolya főigazgató- } \\
\text { val }\end{array}$ & szerkesztőség & 2017. 1. szám \\
\hline 123 & $\begin{array}{l}\text { A korai iskolaelhagyás csökkentését célzó szakpolitika - } \\
\text { ismertető }\end{array}$ & Solymossy J & 2016. 4. szám \\
\hline 115 & A nők dohányzása & $\begin{array}{l}\text { Kárpáti T, Kiss J, } \\
\text { Demjén T }\end{array}$ & 2017. 1. szám \\
\hline 110 & $\begin{array}{l}\text { A rendszeres reggelizés mint szokáskialakítás és érték- } \\
\text { közvetítés a középiskolás korosztályban }\end{array}$ & Lelovics Zs & 2017. 1. szám \\
\hline 104 & Félúton vagy tévúton? & szerkesztőség & 2017. 2. szám \\
\hline
\end{tabular}


A cikkek elérhetőségét is figyelembe vevő rangsorban is első helyen szerepel a Réthy doktor által ismertetett irányelvek bemutatása, és itt is megtalálható a két szerkesztőségi közlés. [3. táblázat] Említésre méltó továbbá a Szabó-Pikó szerzőpáros kutatása és a komplex egészségfejlesztésről szóló írás. Kiemelt figyelmet kapott még az egészségkultúrát érintő két ismertetés és a Magyar Védőnők Egyesületének szakmai tájékoztatója. Az Egészségjelentés2016 megjelenését bejelentő írás magas olvasottsága bizakodásra adhat okot, hiszen a jelentés a szakmai munka tényekre alapozásához nyújthat segítséget.

3. táblázat: A közlemények elérhetőségét is figyelembe vevő olvasottsági rangsora

\begin{tabular}{|c|c|c|c|}
\hline „Érdekesség” & Közlemény címe & Szerző(k) & Lapszám \\
\hline 4,58 & $\begin{array}{l}\text { A csecsemőkori allergia-megelőzés korszerű irányelvei és } \\
\text { lehetőségei }\end{array}$ & Réthy $\mathrm{A}$ & 2017. 1. szám \\
\hline 1,66 & Félúton vagy tévúton? & szerkesztőség & 2017. 2. szám \\
\hline 1,58 & $\begin{array}{l}\text { Az étkezési magatartás összefüggése az ételválasztási } \\
\text { motivációkkal és pszichológiai jellemzőkkel középiskolá- } \\
\text { sok körében }\end{array}$ & Szabó K, Pikó B & 2017. 2. szám \\
\hline 1,42 & $\begin{array}{l}\text { Komplex egészségfejlesztési beavatkozások lehetséges } \\
\text { prevenciós megközelítései }\end{array}$ & Járomi É, Kimmel Zs & 2017. 2. szám \\
\hline 1,02 & $\begin{array}{l}\text { Hogyan befolyásolja a kultúra az egészséget és a jóllé- } \\
\text { tet? I. rész: Az egészség kulturális beágyazottsága }\end{array}$ & Vitrai J & 2017. 2. szám \\
\hline 0,98 & $\begin{array}{l}\text { Az iskolai egészségfejlesztés hazai és nemzetközi szemlé- } \\
\text { letének bemutatatása }\end{array}$ & Járomi É, Vitrai J & 2017. 1. szám \\
\hline 0,97 & $\begin{array}{l}\text { VÉDŐNŐ - Magyar Védőnők Egyesületének szakmai tájé- } \\
\text { koztatója }\end{array}$ & -- & 2017. 2. szám \\
\hline 0,96 & $\begin{array}{l}\text { Hogyan befolyásolja a kultúra az egészséget? II. rész: } \\
\text { Táplálkozás, kultúra és egészség }\end{array}$ & Nagy B & 2017. 2. szám \\
\hline 0,91 & Megjelent az Egészségjelentés2016 & Varsányi P & 2017. 2. szám \\
\hline 0,83 & $\begin{array}{l}\text { Beszélgetés a folyóiratról Dr. Surján Orsolya főigazgató- } \\
\text { val }\end{array}$ & szerkesztőség & 2017. 1. szám \\
\hline
\end{tabular}

A lap szerkesztői remélik, hogy az Egészségfejlesztés legújabb számával sikerül tovább növelni a folyóirat olvasottságát és bővíteni az elért szakemberek körét.

\section{A 2017/3-es lapszám tartalmából ízelítőként:}

Az őszi lapszámunk írásai sokféle népegészségügyi határterületet érintenek, reményeink szerint így szélesebb olvasótábor számára lehetnek fontosak és hasznosak.

Főként a népegészségügyi szakembereket érdekelheti az akut szívizominfarktus ellátási területi egyenlőtlenségeinek elemzése az Eredeti közlemények rovatában. Az eredmények közül kiemelhető, hogy az infarktusos halálesetek földrajzi egyenlőtlensége a gazdasági válság előtti időszakhoz képest megnőtt a nők körében.

A nemi betegségek kórokozóiról jelent meg ismertető az Áttekintő közlemények rovatban, amely a középiskolásoknak szánt fontos információkat foglalja össze a pedagógusok számára.

Az Agora rovatban a 25 éves győri Alapellátási Szabadegyetemet mutatja be az egyik szervező, elsősorban az alapellátásban tevékenykedők érdeklődésére számítva. Nem csak az egészségfejlesztési szakembereknek lehet érdekes az az írás, amely a gyakorlatban felmerülő problémák hátterére nagyobb rálátást és az összefüggések mélyebb megértését kínálja az ökoszociális modell bemutatásával. 
A népegészségügyi adatgyűjtésekről az Egészségügyi Világszervezet által kiadott irányelv minden népegészségügyi szakember számára feltétlenül ajánlott.

A Szakdokumentumok rovat másik ismertetésének címe, „Hogyan fejlesszük egy ország egészségkultúráját?" már önmagában is felkeltheti a szakemberek figyelmét.

A Beszámolók rovatban ismertetett amerikai tankönyv az egészségmagatartás populációs szintű megváltoztatásával kapcsolatos tudást összegzi. Az ismertető főként az egyetemi oktatók és hallgatók érdeklődésére tarthat számot. Egy érdekes Semmelweis-ünnepségről is olvashatnak rövid beszámolót a rovatban.

A Folyóiratszemle rovatban most különösen gazdag témaválasztékot találhatnak az érdeklődő olvasók. A nemzetközi sajtóválogatásban „forró” témák, szerepelnek az egészséges táplálkozástól és a fizikai aktivitástól kezdve, az iskolai egészségfejlesztés eredményességén keresztül az elhízás megelőzését célzó központi és helyi szakpolitikáig.

Kellemes olvasást kívánnak a folyóirat szerkesztői! 